\title{
FRESHWATER BIODIVERSITY AND CONSERVATION CHALLENGES: A REVIEW
}

\author{
Sandeep Arya \\ Institute of Environment and Development Studies \\ Bundelkhand University, Jhansi (U.P.), India \\ *Corresponding author: drsanarya@rediffmail.com
}

Article Info:

Review Article

Received

20.12.2020

Reviewed

15.01.2020

Accepted

11.02.2021

\begin{abstract}
The distinctive feature of Earth is life, and the most exclusive and extraordinary feature of existing life is its vast diversity. Currently, natural freshwater resources are under critical crisis. A contemporary environmental issue is basically conservation of freshwater biodiversity which will lead to the strengthening of ecosystem resilience. It was detected that the reality of increasing anthropogenic activities were continuously degrading the earth's aquatic ecosystem. The conservation of freshwater resources are the most unprecedented challenges for human interferences ranging from depletion of physical structure to extinction of gens, species and biological traits at an alarming rate. Overexploitation, loss of aquatic habitat and fragmentation, water pollution, destruction by land use activities, the introduction of invasive aquatic species, over harvesting and changes in geochemical cycles and global climate change are major threats to freshwater biodiversity. Human survival is basically affected by the loss of aquatic biodiversity as well as being plaintive for its own sake. Biodiversity can be conserved only by proper understanding, knowing the facts of proper planning and effective management of human affairs.
\end{abstract}

Keywords: Adaptation, Biodiversity, Conservation planning, Ecosystem, Freshwater.

\section{INTRODUCTION}

In all over the world, India is rich in biodiversity, contains several globally significant biodiversity hotspots. The term biodiversity means the variety of genes, species, and ecosystems that constitute life on Earth, provides basic needs for livelihoods and development of human beings (Laxmi et al., 2015; Watson et al., 2012 and Rands et al., 2010). Water is not only significant for human beings but also plays an imperative role to balance the entire ecosystem. The major need for water is to sustain biological life, although this, it is a serious issue for the existence of all living organisms (McKinney, 1963). Fresh water is naturally occurring water on the surface of earth in ice sheets, ice caps, glaciers, icebergs, bogs, ponds, lakes, rivers and streams and underground as groundwater in aquifers and underground streams.

Fresh water is generally characterized by having low concentrations of dissolved salts and other total dissolved solids. Terrestrial as well as aquatic biodiversity is completely dependent on water systems and their flow characteristics. Fresh water makes up only $0.01 \%$ of the world's water and approximately $0.8 \%$ of the Earth's surface, yet this small fraction of global water supports at least 100,000 species out of approximately 1.3 million described species. Inland water and freshwater biodiversity constitute a valuable natural resource in 
economic, cultural, aesthetic, scientific and educational terms (Dudgeon et al., 2006). An estimated 126,000 described species rely on freshwater habitats, including species of fishes, mollusks, reptiles, insects, plants, and mammals. With the inclusion of unidentified species, this number could rise to over one million. Species richness in relation to area of habitat is extremely high in many freshwater groups. Freshwater habitats are very susceptible to environmental change and show marked ecological gradients. Standing waters appear to harbor more dispersive species than running waters, but there is little understanding of how this essential ecological difference has affected diversification (Dijkstra et al., 2014). However, of all the world's global ecosystems, freshwater ecosystems are under most pressure (Naimam et al., 2006). Natural systems are essential to produce a wide variety of ecosystem goods and services, ranging from direct use of certain species for food or medicines to ecosystem functions that provide water purification, nutrient retention or climate regulation and other natural assets.

Biodiversity also includes the elements of cultural and spiritual values (Polasky et al., 2005). The area of natural habitat has declined as humans have converted lands to agriculture, industrial establishment and urbanization. The conservation of freshwater biodiversity represents thus a great challenge to scientists, local managers and policy makers. Management of freshwater biodiversity has to take into account trade-offs between biodiversity protection and sustainable use (Naiman et al., 2006). Freshwater biodiversity is facing unprecedented levels of threat. Hence, through this review article, I want to draw attention and raise awareness about these threat to delicate ecosystems. This paper chieflyemphaseson harmful negative effects of biodiversity management and move away from focusing on very short-term gains.

\section{FRESH WATER ECOSYSTEM}

Fresh water ecosystems encompass ecological, social and economic processes (ecosystem functions) that interconnect organisms (ecosystem structure) including humans and helpful in maintaining the biodiversity. Fresh water habitats are rich in biodiversity including rivers, lakes and wetlands. The biodiversity has different levels and values (Ashok, 2016). The genetic diversity acts as a buffer for biodiversity (Verma, 2017a). The biodiversity helps in maintaining the ecological balance. There is a necessity of ecological balance for widespread biodiversity (Verma 2017b) and the biodiversity loss has ecological impact (Kumar and Verma, 2017). The ecological balance is an indispensable need for human survival (Ashok, 2018).

The fresh water ecosystems impart several services such as drinking water, food i.e. fish, transport as well as recreational opportunities. Fresh water is basically water without salt, which differentiates these environments from marine, brackish water and freshwater ecosystems (Coates and Grekin, 2018).

Habitats of freshwater existing in rivers, streams, springs and headwaters are heterogeneous due to variations in altitudes, flow rates, dissolved oxygen, physical substrate and the riparian zones that provide food, shade and cover (Armantrou, 1990). Freshwater habitat harbors diverse fauna (Karr et al., 1986). This has been also observed that unfortunately freshwater ecosystem are some of the most endangered habitats in the world and have alarming rates of species extinction. Fresh water and the biodiversity are vital importance to all life and sensitive to nearly any kind of human activity i.e. industrial production, navigation, domestic water requirements, waste assimilation, health, and especially food production (Postel and Carpenter, 1997; Gleick, 2001). Freshwater ecosystems are part of the landscape and interact with land i.e., rainwater falling on land flows into streams and rivers, and fills up lakes and wetlands, carrying with its nutrients and plant material such as seeds and leaves. In other world, they provide water to recharge water stored below ground, which supports plants living on land such as forests (Coates and Grekin, 2018)

\section{Fresh Water Life}

A hypothetic environment is created for aquatic organism by fresh water. At the species level, it includes life, which is very obviously living in 
freshwater but also includes life which is adapted to live in or around freshwater habitats. It endures a fairly diverse community, which include several species of algae, rooted and floating aquatic plants, grazing snails, clams, insects, crustaceans, fishes, amphibians and reptiles.

\section{IMPORTANCE OF FRESH WATER BIODIVERSITY}

Food: Inland fisheries can provide the primary source of animal protein for many rural communities in developing countries. Aquaculture, the farming of fish and other aquatic animals e.g. shrimp, can also provide food and source of income for many people, as can wetland agriculture, such as rice farming.

Fiber: Many wetland plants have been a source of fiber throughout human history for making such items as baskets, roofs, paper and rope.

Recreational and cultural benefits: Many rivers, lakes and wetlands are highly valued for recreational and cultural benefits, some of which have high economic value such as tourism. Sport fishing is also an important recreational activity and a significant source of income for many communities in developed countries. Recreational fishers have been a major driving force in cleaning up freshwater environments to restore recreational benefits.

Carbon storage: Large quantity of release of carbon dioxide and other greenhouse gases into the atmosphere leads to climate change. Wetlands, particularly peatlands, are 'carbon sinks'. They remove and store significant quantities of carbon from the atmosphere. Peatlands alone store more than twice as much carbon than all the world's forest. Destruction of these wetlands results in the increase of carbon into the atmosphere, increasing the intensity of global climate change. Anthropogenic activities have destroyed almost 25 percent of the peat lands on Earth.

Water purification and filtration: plants, animals and bacteria in forests, soils and wetlands also filter and purify water. Wetland plants collect excess nutrients (such as phosphorus and nitrogen) and toxic substances such as heavy metals in their tissues, eliminating them from the surrounding water and preventing toxic metals from reaching drinking water. They can be thought of as "nature's kidneys".

Flood regulation: Many wetlands provide a natural flood barrier. Peatlands, wet grasslands and floodplains at the source of streams and rivers act like sponges, absorbing excess rainwater runoff and spring snowmelt, releasing it slowly into rivers and allowing it to be absorbed more gradually into the soil, preventing sudden, damaging floods downstream. Coastal freshwater-dependent wetlands, such as mangroves, salt marshes, tidal flats, deltas and estuaries, can limit the damaging effects of storm surges and tidal waves by acting as physical barriers that reduce the water's height and speed.

\section{Threats to Freshwater Biodiversity}

Major threats to freshwater biodiversity consists of existing and potential dams, water obstruction and reduced flows, conversion of habitat, enrichment of both surface and groundwater, overuse of water, riparian degradation, pollution, changing in climatic conditions, artificial channeling of rivers, weed growth, introduction of alien species, illegal fish liberation, sports and indigenous fish competition, commercial fishing pressure, blocking of migratory fish passage, inappropriate recreational activity, riverbed engineering work, and wetland drainage or lowered water levels for both agriculture and urban purposes. Often these threats act together and heighten the stress that have the adverse impact on freshwater biodiversity.

\section{Conservation Strategies}

The first step in protecting biodiversity is to become aware of where fresh waters comes from and how much we depend on it; not just for what we drink, but for personal hygiene, growing our food and producing energy and the goods we consume (Coates and Grekin, 2018). Biodiversity is the 'foundation of human life' on earth and for human's survival and sustainable development; it must be maintained at any cost (Verma and Prakash, 2020) but environmental ethics should 
be followed (Verma, 2019). Always try to use environment friendly products as possible. Only after treatment, disposal of toxic and hazardous material unavoidable, on other hand chemicals that enter the sewer system contaminate freshwater and ocean ecosystems. Support local Government initiatives and policies that conserve habitat and decrease threats to aquatic biodiversity. Learn as much as you can about nature, wildlife and environment and share your knowledge and ideas with others. To aware and encourage other people to raise their hands in conserving these ecosystems. Increasing the complexity and realism of experiments, however, will not be enough to move biodiversity research towards better forecasting. We also need sets of models and statistical tools that help us to move from local biological experiments to landscapescale patterns where management and policy take place (Cardinale et al., 2012).

\section{CONCLUSION}

In the era of development and globalization, conservation of natural resources especially freshwater is matter of concern to all. The conservation of freshwater biodiversity is a current environmental issue, which is the only way to save to the biodiversity. Sustaining aquatic biodiversity in the face of increasing human populations and their intensive activities promises to be a major challenge. Due to current trends in continuous habitat destruction and increasing human demands for water, the prospect to conserve much of the remaining freshwater biota will be lost in near future. Successful conservation efforts will require management that simultaneously keeps in mind the needs of Homo sapiens and other species. Ecologists and conservationists have an important role to play in helping to develop and evaluate simple and very effective conservation policies.

\section{REFERENCES}

1. Armantrou N. B. (1990). Conservation in Developing Countries In: Daniel J. C. and J. S. Serrao (eds.) Problems and prospects, Proceedings of centenary seminar on the Bombay National History Society. 656p.
2. Ashok K.V. (2016). Biodiversity: Its Different Levels and Values. International Journal on Environmental Sciences. 7(2): 143:145.

3. Ashok K.V. (2018). Ecological Balance: An Indispensable Need for Human Survival. Journal of Experimental Zoology, India. 21(1): 407-409.

4. Cardinale B. J., Duffy J. E., Gonzalez A., Hooper D. U., Perrings C., Venail P., Narwani A., Mace J. B., Larigauderie A., Srivastava D. D. and Naeem S. (2012). Biodiversity loss and its impact on humanity. Nature. 486 (7401): 59-67. 10.1038/nature 11148.

5. Coates D. and Grekin J. (2018). Freshwater Biodiversity: Dive into the life found in freshwater ecosystems. CBD. Youth and United Nation Global Alliance. 85-101p.

6. Dijkstra K. D. B., Monaghan M. T. and Pauls S. U. (2014). Freshwater Biodiversity and Aquatic Insect Diversification. Annual Review of Entomology. 59: 143-163. 10.1146/annurev-ento-011613-161958.

7. Dudgeon D., Arthington A. H., Gessner M. O., Kawabata Z., Knowler D. J., Le've'que C., Naiman R. J., Richard A. H. P., Soto D., Stiassny M. L. J. and Sullivan C. A. (2006). Freshwater biodiversity: importance, threats, status and conservation challenges. Biological Reviews. 81(2): 163-182. 10.1017/ S1464793 105006950.

8. Gleick P. H. (2001): Safeguarding our watermaking every drop count. Scientific American. 284: 40-45.

9. Karr J. R., Fausch K. D., Angermeier P. L., Yant P. R. and Schlosser I. J. (1986) Assessing biological integrity in running waters: a method and its rationale III. Natural History Survey. 5:28.

10. Kumar Ajay and Verma A. Kumar (2017). Biodiversity loss and its Ecological impact in India. International Journal on Biological Sciences. 8(2): 156-160.

11. Laxmi R., Arya S., Sultana A. and Das S. (2015). Assessment and Impact of Industrial Effluents on River Yamuna Ecosystem. International Journal of Current Research. 7(9): 19956-19963. 
12. McKinney R. E. (1963). The Need and Importance of Fresh Water for Mankind. The Kansas Academy of Science. 66 (1):14-16.

13. Naiman R. J., Prieur-Richard A. H., Arthington A., Dudgeon D., Gessner M. O., Kawabata Z., Knowler D., O'Keeffe J., Lévêque C., Soto D., Stiassny $M$. and Sullivan C. (2006). Freshwater Biodiversity: Challenges for freshwater biodiversity research. DIVERSITAS Report $N^{\circ} 5.48 p$.

14. Polasky S., Costello C. and Solow A. (2005). The Economics of Biodiversity, handbook of Environmental Economics, Edited by K.G. Maler and J.R. Vincent. Chapter 29. Vol 3.

15. Postel S. L. and Carpenter S. R. (1997). Freshwater ecosystem services. In: Nature's Services: Societal Dependence on Natural Ecosystems, edited by G.C. Daily. Island Press, Washington, DC. 195-214p.

16. Rands M. R., Adams W. M., Bennun L., Butchart S. H., Clements A., Coomes D., Entwistle A., Hodge I., Kapos V., Scharlemann J .P., Sutherland W. J. and Vira B. (2010). Biodiversity conservation: challenges beyond 2010. Science. 329(5997): 1298-1303. 10.1126/science. 1189138.
17. Verma A.K. (2017a). Genetic Diversity as Buffer in Biodiversity. Indian Journal of Biology. 4(1): 61-63. http://dx.doi.org/ 10.21088/ijb.2394.1391.4117.9.

18. Verma A.K. (2017b). Necessity of Ecological Balance for Widespread Biodiversity. Indian Journal of Biology. 4(2): 158-160. http://dx.doi.org/10.21088/ijb.2394.1391.421 7.15

19. Verma A. Kumar (2019). Sustainable Development and Environmental Ethics. International Journal on Environmental Sciences. 10 (1): 1-5.

20. Watson J. E. M., Rao M. and Yan K. A. L. X. (2012). Climate Change Adaptation Planning for Biodiversity Conservation: A Review. Advances in Climate Change Research. 3(1): 1-11.

21. Watson J. E. M., Rao M. and Yan K. A. L. X. (2012). Climate Change Adaptation Planning for Biodiversity Conservation: A Review. Advances in Climate Change Research. 3(1): 1-11 